\title{
Hubungan antara pengasuhan orangtua dengan masalah makan pada anak usia prasekolah
}

\author{
Riswan ${ }^{1}$, Eva Yunitasari $\left.{ }^{*}\right)$ \\ ${ }^{\left.1,2^{*}\right)}$ Program Studi S1 Keperawatan Fakultas Kesehatan Universitas Aisyah Pringsewu
}

\section{ARTICLE INFO}

\section{Keyword:}

Parenting

Difficult Eating Behavior

Children's Preschool

\section{*) corresponding author}

Dosen Program Studi S1 Keperawatan

Fakultas Kesehatan, Universitas Aisyah

Pringsewu

Jl. A Yani No. 1 A Tambak Rejo, Wonodadi, Kec. Pringsewu, Kabupaten Pringsewu, Lampung 35372

Email:

eva.maternitynursing@gmail.com

https://doi.org/10.47679/makein.011.42000005

\begin{abstract}
A B S T R A C T
Parenting is very important in the child's psychological growth and development, the child's ability to socialize, children's independence, and difficult eating behavior in children. Because of the phenomenon that often arises is the child has difficult eating which is influenced by parenting parents. This research objective was to determine the correlation between parenting parents with difficult eating behavior on children's pre-school age at the Sindang Garut village of Way Lima sub-district in Pesawaran Regency. This research was quantitative type with cross sectional approach to the sampling technique used is purposive sampling. The sample were 30 respondents. Data collection used questionnaire sheets and it used gamma statistical tests. The results showed that parenting parents applied were democratic parenting (56.7 percent), and difficult eating behavior in children's pre-school age at the Sindang Garut village with low intensity (73.3 percent) with $p$ value of 0.006 less than 0.05 , which means there is a correlation between parenting parents with difficult eating behavior in children's pre-school age at the Sindang Garut village of Way Lima subdistrict in Pesawaran Regency. So this research is expected to be a source of reference and information for parents about the importance of parenting because it can influence the behavior of eating difficulties on children.
\end{abstract}

This open access article is under the CC-BY-SA license.
Kata kunci:

Pola Asuh Orang Tua

Perilaku sulit makan

Anak Usia Prasekolah

\section{A B S T R A K}

Pola asuh orang tua sangat penting dalam tumbuh kembang anak dalam psikologis anak, kemampuan bersosialisasi anak, kemandirian anak, serta perilaku sulit makan pada anak. Karna fenomema yang sering muncul adalah anak mengalami sulit makan yang dipengaruhi oleh pola asuh orang tua. Penelitian ini bertujuan untuk mengetahui hubungan pola asuh orang tua dengan perilaku sulit makan pada anak usia prasekolah di desa sindang garut kecamatan way lima kabupaten pesawaran. Penelitian ini merupakan jenis peneltian kuantitatif dengan pendekatan Cross Sectional teknik pengambilan sampel yang digunakan adalah purposive sampling. dengan jumlah sampel 30 responden. Pengumpulan data menggunakan lembar kuesioner dan uji statistik gamma. Hasil penelitian menunjukan mayoritas pola asuh yang diterapkan adalah pola asuh demokratis (56,7 persen), dan perilaku sulit makan pada anak di desa sindang garut dengan intensitas rendah (46,7 persen) dengan nilai $\mathrm{p}$ value 0,006 kurang dari 0,05 , yang artinya ada hubungan pola asuh orang tua dengan perilaku sulit makan pada anak usia prasekolah di desa sindang garut kecamatan way lima kabupaten pesawaran. Maka penelitian ini diharapkan bagi orang tua agar dapat menerapkan pola asuh demokratis sehingga dapat mengurangi kejadian sulit makan pada anak usia prasekolah.

This is an open access article under the CC-BY-SA license. 


\section{PENDAHULUAN}

Status gizi pada anak akan menentukan tahap pertumbuhan dan perkembangan terutama gizi yang diperoleh pada usia prasekolah akan menentukan tahap berikutnya karna keduanya berjalan bersamaan dan saling mempengaruhi pertambahan kemampuan pada anak dengan pertambahan ukuran tubuh (Warouw dan Rottie 2013 dalam Laili wiji Rahmawati 2018). Namun sebagian orang tua belum memperhatikan kandungan gizi pada tubuh anak (Setyorini, 2017).

Permasalahan gizi masih perlu mendapatkan perhatian dari berbagai pihak menurut data WHO (2018) 38 juta (5,6\%) balita didunia pada tahun 2017 mengalami over weight. Hasil pemantauan gizi di Indonesia menurut (Riskesdas 2018), terdapat $17,7 \%$ status balita kekurangan gizi dengan $3,9 \%$ status balita gizi buruk dan $13,8 \%$ status balita gizi kurang. Prevalensi di Lampung diketahui terdapat 15,9\% status balita kekurangan gizi dengan 3,1\% status balita gizi buruk dan $12,8 \%$ status balita kurang gizi. Dan di kabupaten Pesawaran terdapat 21,3\% status balita kekurangan gizi dengan $3,79 \%$ status balita gizi buruk dan $17,51 \%$ status balita kurang gizi (Kemenkes, 2018).

Anak pra sekolah adalah mereka yang berusia antara 3-6 tahun. Anak pada usia prasekolah biasanya mengalami perkembangan psikis menjadi balita yang lebih mandiri, autonom, dan dapat berinteraksi dengan lingkungannya, serta dapat lebih mengekspresikan emosinya. Di samping itu anak usia tersebut juga cenderung senang bereksplorasi dengan hal-hal baru. Sifat perkembangan khas yang terbentuk ini turut mempengaruhi pola makan anak (Hidayat, 2013 dalam Katiandagho dkk, 2016).

Permasalahan pada anak usia prasekolah (3-6 tahun) adalah bahwa pada usia ini seorang anak masih merupakan golongan konsumen pasif yaitu belum dapat mengambil dan memilih makan sendiri. Maka pada usia ini anak dengan kesulitan makan rentan terhadap berbagai penyakit infeksi terutama kondisi kurang gizi (Santoso, 2014).

Angka kejadian masalah kesulitan makan di beberapa Negara termasuk cukup tinggi. Sebuah penelitian The Gates head Millenium Baby Study pada tahun 2014 di Inggris menyebutkan $20 \%$ orang tua melaporkan anaknya mengalami masalah makan, dengan prevalansi tertinggi anak hanya mau makan makanan tertentu. Study di italia mengungkapkan 6\% bayi mengalami kesulitan makan, kemudian meningkat pada fase akhir pertumbuhan. Survey lain di Amerika Serikat menyebutkan $19-50 \%$ orang tua mengeluh anaknya sangat pemilih dalam makan sehingga terjadi defisiensi zat gizi tertentu (Waugh, 2014). Kesulitan makan yang berat dan berlangsung lama berdampak negatif pada keadaan kesehatan anak, keadaan tumbuh kembang dan aktifitas sehari-harinya (Karaki, 2016).

Sikap orang tua dan hubungannya dengan anak atau biasa yang disebut pola asuh, sangat menentukan terjadinya gangguan psikologis yang dapat mengakibatkan gangguan makan. Gangguan makan disebabkan oleh perlindungan dan perhatian berlebihan pada anak, orang tua yang pemarah, tegang terus menerus, kurangnya kasih sayang baik secara kualitas dan kuantitas, kurangnya pengertian dan pemahaman orang tua terhadap kondisi psikologis anak (Nafratilawati, 2014).

Pola asuh ibu sangat penting dalam tumbuh kembang anak dalam psikologis anak, kemampuan bersosialisasi anak, kemandirian anak, serta perilaku sulit makan pada anak. Sikap ibu dapat membentuk karakter anak menjadi sulit makan adalah cara menyiapkan makanan, cara memberikan anak makan, menenangkan anak dengan meberikan makanan ringan, memaksa anak untuk makan, terlambat memberikan makanan padat, dan ibu tidak membiasakan anak makan tepat waktu (Nafratilawati, 2014).

\section{METODE}

Penelitian ini merupakan jenis penelitian kuantitatif dengan desain penelitian survey analitik, menggunakan pendekatan cross sectional. Teknik pengambilan sampel menggunakan purposive sampling, dengan jumlah 30 orang tua anak di desa Sindang Garut yang memiliki anak usia prasekolah.

\section{HASIL DAN PEMBAHASAN}

Tabel 1

Distribusi frekuensi responden berdasarkan Tingkat Pengetahuan dan perilaku merokok (N=98)

\begin{tabular}{lcc}
\hline \multicolumn{1}{c}{ Variabel } & Jumlah & Presentase \\
\hline Usia & 4 & 13,3 \\
\hline $20-30$ & 21 & 70,0 \\
\hline $31-40$ & 5 & 16,7 \\
\hline $41-50$ & & \\
\hline Tingkat Pendidikan & 6 & 20,0 \\
\hline SD & 16 & 53,3 \\
\hline SMP & 8 & 26,7 \\
\hline SMA & & \\
\hline Pekerjaan & 20 & 66,7 \\
\hline Ibu Rumah Tangga & 10 & 33,3 \\
\hline Wiraswasta & & 20,0 \\
\hline Pola asuh orangtua & 6 & 56,7 \\
\hline Otoriter (73-90) & 17 & 23,3 \\
\hline Permisif (36-72) & 7 & \\
\hline Demokratis (18-35) & & 13,3 \\
\hline Perilaku sulit makan & 4 & 40,0 \\
\hline Tinggi (37-50) & 12 & 46,7 \\
\hline Sedang (24-36) & 14 & \\
\hline Rendah (10-23) & & \\
\hline
\end{tabular}


Tabel 2

Hubungan tingkat pengetahuan tentang rokok perilaku merokok (N=98)

\begin{tabular}{|c|c|c|c|c|c|c|}
\hline \multirow{2}{*}{ Kategori Pola Asuh } & \multicolumn{3}{|c|}{ Kategori Sulit Makan } & \multirow[b]{2}{*}{ Total } & \multirow[b]{2}{*}{ Koofisien } & \multirow[b]{2}{*}{ Nilai $F$} \\
\hline & Tinggi & Sedang & Rendah & & & \\
\hline Otoriter & $\begin{array}{c}4 \\
66,7 \% \\
\end{array}$ & $\begin{array}{c}1 \\
16,7 \% \\
\end{array}$ & $\begin{array}{c}1 \\
16,7 \% \\
\end{array}$ & $\begin{array}{c}6 \\
100,0 \% \\
\end{array}$ & & \\
\hline Permisif & $\begin{array}{c}0 \\
0,0 \%\end{array}$ & $\begin{array}{c}9 \\
52,9 \% \\
\end{array}$ & $\begin{array}{c}8 \\
47,1 \% \\
\end{array}$ & $\begin{array}{c}17 \\
100,0 \% \\
\end{array}$ & 0,05 & 0,006 \\
\hline Demokratis & $\begin{array}{c}0 \\
0.0 \%\end{array}$ & $\begin{array}{c}2 \\
28,6 \% \\
\end{array}$ & $\begin{array}{c}5 \\
71,4 \% \\
\end{array}$ & $\begin{array}{c}7 \\
100,0 \% \\
\end{array}$ & & \\
\hline Total & $\begin{array}{c}4 \\
13,3 \% \\
\end{array}$ & $\begin{array}{c}12 \\
40,0 \% \\
\end{array}$ & $\begin{array}{c}14 \\
46,7 \% \\
\end{array}$ & $\begin{array}{c}30 \\
100,0 \% \\
\end{array}$ & & \\
\hline
\end{tabular}

Berdasarkan tabel 1 diketahui bahwa dari 30 responden, mayoritas usia orang tua adalah 31-40 sebanyak 21 (70,0\%). Dari tingkat pendidikan mayoritas orang tua adalah smp sebanyak 16 (53,3\%). Dan dari pekerjaan orang tua mayoritas yaitu ibu rumah tangga sebanyak 20 (66,7\%). Hasil penelitian dari 30 responden, terdapat 7 responden $(23,3 \%)$ memiliki pola asuh demokratis dan 17 responden $(56,7 \%)$ memiliki pola asuh permisif dan 6 responden (20,0\%) memiliki pola asuh otoriter. Terdapat 14 responden $(46,7 \%)$ memiliki sulit makan rendah, 12 responden (40,0\%) memiliki sulit makan sedang dan sisanya terdapat 4 responden (13,3\%) memiliki sulit makan tinggi.

Hasil penelitian menunjukkan bahwa anak yang mendapatkan pola asuh otoriter memiliki perilaku sulit makan dengan intensitas tinggi sebanyak (66,7\%), sedang (16,7\%), rendah (16,7\%), sedangkan anak yang mendapatkan pola asuh permisif memilki perilaku sulit makan dengan intensitas sedang (52,9\%) rendah (47,1\%), dan anak yang mendapatkan pola asuh demokratis memiliki perilaku sulit makan dengan intensitas sedang sebanyak (28,6\%), dan rendah $(71,4 \%)$ (Tabel 2$)$.

Hasil dari penelitian menunjukan bahwa dari 6 orang tua (20\%) menerapkan pola asuh otoriter, terdapat 1 anak $(16,7$ \%) yang memiliki tingkat perilaku sulit makan dengan intensitas rendah, dan terdapat 1 anak (16,7 \%) yang memiliki perilaku sulit makan dengan intensitas sedang, dan 4 anak (66,7 \%) yang memiliki perilaku sulit makan dengan intensitas tinggi.

Dari 17 orang tua (56,7 \%) yang menerapkan pola asuh permisif, terdapat 9 anak (52,9\%) yang memiliki perilaku sulit makan dengan intensitas sedang, dan 8 anak (47,1\%) yang memiliki perilaku sulit makan dengan intensitas rendah.

Dan dari 7 orang tua $(23,3 \%)$ yang menerapkan pola asuh demokratis, terdapat 5 anak $(71,4 \%)$ yang memiliki perilaku sulit makan dengan intensitas rendah, dan 2 anak (28,6 \%) yang memiliki perilaku sulit makan dengan intensitas sedang. Dari hasil penelitian ini menunjukan bahwa di desa sindang garut orang tua lebih banyak menerapkan pola asuh demokratis.

Berdasarkan penelitian ini dapat dilihat bahwa pola asuh yang diterapkan orang tua pada anak usia prasekolah akan berpengaruh pada perkembangan anak, salah satunya adalah perkembangan pada perubahan pola makan anak dimana pada umumnya mengalami kesulitan makan.

Hasil penelitian Karaki (2016) pola asuh ibu dengan perilaku sulit makan pada anak usia prasekolah memiliki hubungan yang berarti, menunjukan bahwa pila asuh sangan mempengaruhi tumbuh kembang anak terlebih kebiasaan makan sehingga pola asuh yang kurang baik dapat menyebabkan anak mengalami perilaku sulit makan.

Pola asuh orang tua sangat penting dalam tumbuh kembang anak, kemampuan bersosialisasi, keandirian anak, serta perilaku sulit makan anak. Selain itu orang tua dapat membentuk karakter anak menjadi sulit makan adalah cara menyiapkan makan, cara memberikan makan, menenangkan dengan memberikan anak makanan ringan, memaksa anakuntuk makan, terlambat memberikan makanan padat, dan orang tua tidak membiasakan anak makan tepat waktu (Nafratilawati, 2014).

Hal ini sangat sejalan dengan penelitian Marianna, S., \& Hardyanti, E. (2019). Berdasarkan hasil penelitian hubungan pola asuh orang tua terhadap perilaku sulit makan anak usia prasekolah di BIMBA AIUEO Griya Bintara Bekasi yang dilakukan pada orang tua sebanyak 31 responden, dapat disumpulkan mayoritas orang tua menerapkan pola asuh demokratis yaitu berjumlah 51,6\%. Terdapat lebih banyak anak prasekolah mengalami perilaku tidak sulit makan.

Soetjiningsih (2013), kesulitan makan dapat disebabkan oleh beberapa faktor, antara lain kelainan kebiasaan makan, kelainan psikologis, dan kelainan organik. Menurut peneliti kelainan kebiasaan makan biasanya disebabkan oleh faktor lingkungan seperti mengikuti kebiasaan makan teman sebaya atau orang-orang sekitar, menyukai dan menolak jenis makanan yang sama pada waktu yang berbeda, atau suka memakan makanan yang tidak sesuai dengan usianya.

Asumsi peneliti berdasarkan dari hasil penelitian dan analisis didapat nilai $p$-value $=0,006<\alpha(0,05)$, menunjukkan adanya hubungan yang signifikan antara pola asuh orang tua dengan perilaku sulit makan pada anak usia prasekolah, ini berarti bahwa pola asuh orang tua sangat penting terhadap pembentukan perilaku dan karakter anak, karena anak seringkali meniru kebiasaan dan perilaku dari orang tua dan ibu menjadi contoh penting bagi anaknya dirumah termasuk menirukan kebiasaan makan ibu. Oleh sebab itu, pola asuh sangat mempengaruhi tumbuh kembang anak terlebih kebiasaan makan sehingga pola asuh yang kurang baik dapat menyebabkan anak mengalami perilaku sulit makan.

\section{KESIMPULAN DAN SARAN}

Rata-rata tingkat usia orang tua adalah 31-40 tahun sebanyak 21 (70,0\%) dan usia $20-30$ sebanyak 4 (13,3\%) dan usia 41-50 tahun sebanyak $5(16,7 \%)$, sedangkan untuk tingkat pendidikan orang tua sd sebanyak 6 (20,0\%), smp 16 $(53,3 \%)$, sma $5(26,7 \%)$. Dan pekerjaan orang tua irt sebanyak 20 (66,7\%), sedangkan wiraswasta sebanyak 10 (33,3\%). Mayoritas orang tua di desa sindang garut menerapkan pola asuh permisif yaitu sebanyak 17 orang (56,7\%).

Mayoritas anak usia prasekolah di desa sindang garut memiliki tingkat perilaku sulit makan dengan intensitas rendah sebanyak 14 anak (46,7\%). 
Dari hasil uji statistic dengan uji gamma diperoleh nilai $p$-value $=0,006<(0,05)$ maka terdapat hubungan antara pola

\section{DAFTAR PUSTAKA}

Anggraini, R. (2014). Hubungan Pola Asuh Orang Tua dengan Motivasi Belajar. Semarang : Skripsi IKIP Veteran Semarang.

Ariani, T. R. (2019). Hubungan Kesulitan Makan Dengan Status Gizi Pada Anak 3-5 Tahun Di Kelurahan Jati Kota Padang Tahun 2019. Doctoral dissertation, Universitas Andalas.

Effendy, N. (2014). Dasar-Dasar Keperawatan Kesehatan Masyarakat. Jakarta:EGC.

Hidayat, A. A. (2013). Pengantar ilmu keperawatan anak 1. Jakarta: Salemba medika.

Herlina, S., \& Nurmaliza, N. (2018). Pola Asuh Dalam Pemberian Makanan Terhadap Status Gizi Balita Di Kota Pekanbaru Tahun 2017. JOMIS (Journal of Midwifery Science), 2(1), 17.

Ikhwan, I., Fattah, A. H., \& Ibrahim, A. (2017). Hubungan Pola Asuh Orang Tua Dengan Perilaku Sulit Makan Pada Anak Usia Pra Sekolah. JIKP Jurnal Ilmiah Kesehatan PENCERAH, 6(2), 83-90.

Judarwanto, W. (2011). Mengatasi Kesulitan Makan pada Anak. Jakarta: Puspa Swara.

Karaki, K. B., Kundre, R., \& Karundeng, M. (2016). Hubungan Pola Asuh Ibu Dengan Perilaku Sulit Makan Pada Anak Usia Prasekolah (3-5Tahun) Di Taman Kanak-kanak Desa Palelon Kec. Modoinding Minahasa Selatan. JURNAL KEPERAWATAN, 4(1).

Katiandagho, N., Mampuk, V. S., \& Watung, G. (2016). Hubungan Pola Asuh Ibu Dengan Perilaku Sulit Makan Pada Anak Prasekolah (3-5 Tahun) di TK GMIM Exodus Paniki Dua. Journal Of Community and Emergency, 4(2), 191-196.

Kesuma, A., Novayelinda, R., \& Sabrian, F. (2015). Faktor Faktor Yang Berhubungan Dengan Perilaku Kesulitan Makan Anak Prasekolah. Doctoral dissertation, Riau University.

Khasanah, N.A. (2014). Hubungan Sikap Ibu Tentang Kesulitan Makan Dengan Status Gizi Anak Usia Prasekolah (3-6 Tahun) Di Desa Wonosari Ngoro Mojokerto.

Lariwu, C., Rottie, J., \& Corneles, P. K. (2019). Hubungan Pola Asuh Ibu Dengan Perilaku Sulit Makan Pada Anak Usia Pra Sekolah Di Paud Pancaran Berkat Desa Ranoketang Atas Kecamatan Tombatu Kabupaten Minahasa Tenggara. Journal of Community and Emergency, 7(2), 192-204.

Loka, L. V., Martini, M., \& Sitompul, D. R. (2018). Hubungan Pola Pemberian Makan Dengan Perilaku Sulit Makan Pada Anak Usia Prasekolah (3-6 Tahun). Jurnal Keperawatan Suaka Insan (JKSI), 3(2), 1-10.

Marianna, S., \& Hardyanti, E. (2019). Hubungan Pola Asuh Orang Tua Dengan Perilaku Sulit Makan Pada Anak Prasekolah. The Shine Cahaya Dunia D-Iii Keperawatan, 4(2).

Nafratilawati, M. (2014). Hubungan Antara Pola Asuh Dengan Kesulitan Makan Pada Anak Usia Prasekolah (3-5 Tahun) Di Tk Leyangan Kabupaten Semarang.

Notoatmodjo, S. (2008). Promosi kesehatan dan ilmu perilaku. Jakarta: Rineka Cipta.

Notoatmodjo, S. (2010). Metode penelitian kesehatan, edisi revisi. Jakarta: PT. Asdi Mahasatya.

Novi, B. (2015). Kebiasaan-Kebiasaan Buruk Sehari-hari Bahayanya Bagi Kesehatan Fisik dan Mental Anak. Yogyakarta: FlashBooks. asuh orang tua dengan perilaku sulit makan pada anak usia prasekolah

Pratiwi, D. P., et all. (2015). hubungan pola asuh orang tua dengan perilaku sosial pada anak prasekolah di TK Pertiwi Rambipuji Jember.

Rahman, A. N. (2016). Hubungan pola asuh ibu dengan perilaku sulit makan pada anak prasekolah di Taman Kanak-kanak Al-Ikhwah Pontianak. Jurnal Keperawatan. Universitas Tanjungpura.

Rahmawati, L, W. (2018). Hubungan Praktik Komprehensif Pemberian Makan Dengan Status Gizi Anak Prasekolah Di Desa Kemuning Kecamatan arjasa Kabupaten Jember. Program Studi Ilmu Keperawatan Fakultas Keperawatan Universitas Jember.

Riskesdas. (2018). Riset Kesehatan Dasar. Jakarta:Riskesdas.

Soetjiningsi, (2013). Tumbuh Kembang Anak Edisi 2. Jakarta: Penerbit Buku Kedokteran EGC, hlm.2-18.

Setyorini, D Y. (2017). Hubungan Tingkat Pengetahuan Ibu dengan Perilaku Pembeian Nutrisi pada Anak di Desa Kemuning Kecamatan Arjasa Kabupaten Jember. Program Studi Sarjana Keperawatan Fakultas Keperawatan Universitas Jember.

Shochib, M. (2010). Pola Asuh Orang Tua Dalam Membantu Anak Dalam Mengembangkan Disipin Diri. Jakarta: Rineka Cipta.

Soedibyo, S., \& Mulyani, R. L. (2016). Kesulitan makan pada pasien: survei di unit pediatri rawat jalan. Sari pediatri, 11(2), 79-84.

Sukirno, R. (2019). Kesabaran Ibu Merawat Bayi Berat Lahir Rendah (BBLR). Journal of Psychological Perspective, 1(2), 1-14. $\quad$ Retrieved from https://ukinstitute.org/journals/jopp/article/view/jop pv1i101

Triaristina, A., \& Mukhlis, H. (2019). Implemetasi Pendidikan Karakter Melalui Media Dongeng Berbasis Visual Pada Anak Usia 4-6 Tahun. Journal of Psychological Perspective, 1(2), 35-40. Retrieved from https://ukinstitute.org/journals/jopp/article/view/jop pv1i105

Utami, A, G. (2017). Hubungan Pola Asuh Orang Tua Dengan Pola Makan Pada Anak Usia Prasekolah Di Tk Rejosari Kec. Sawah Madiun. Program Studi Ilmu Keperawatan STKes Bhakti Husada Mulia Madiun.

Yulianti, Y., Mastuty, A, \& Pratama, E. S. (2019). Analisis Hubungan Pola Asuh Orang Tua Dengan Tingkat Kemandirian Personal Hygiene Pada Anak Usia Pra Sekolah Di Dusun Celegeh Desa Barebali Lombok Tengah Tahun 2019. Jurnal Surya Muda. Jurnal STIKes Muhammadiyah Kendal, 1(2), 78-88. 